\section{Asteridiella ficicola sp. nov. (Meliolaceae) from Kerala, India}

\author{
V.B. Hosagoudar ${ }^{1}$, G.R. Archana ${ }^{2}$ \& T. Sabu ${ }^{2}$ \\ 1,2 Tropical Botanic Garden and Research Institute, Palode, \\ Thiruvananthapuram, Kerala 695562, India \\ Email: ${ }^{1}$ vbhosagoudar@ rediffmail.com
}

During a survey of the foliicolous fungi in Kerala State, Ficus microcarpa L. (Moraceae), an endemic large evergreen tree planted in the garden of Tropical Botanic Garden and Research Institute, Palode, for the conservation purposes, was found infected with a black mildew fungus. Critical examination of the fungus revealed that it is an undescribed species of the genus Asteridiella. Hence, it is described and illustrated in detail.

\section{Asteridiella ficicola sp. nov.}

(Fig. 1)

Coloniae epiphyllae, densae, ad $2 \mathrm{~mm}$ diam., confluentes. Hyphae subrectae vel flexuosae, plerumque opposite vel alternatim acuteque vel laxe ramosae, laxe vel arte reticulatae, cellulae 9-24 x 6-8 $\mu \mathrm{m}$. Appressoria alternate vel unilateralis, recta vel leniter curvula, antrorsa vel subantrorsa, raro retrorsa, 12-2 $1 \mu \mathrm{m}$ longa; cellulae basilares cylindraceae vel cuneatae, 3-8 $\mu \mathrm{m}$ longae; cellulae apicales rectae vel leniter curvulae, globosae, ovatae, oblongae, integrae vel raro angularis, 8-13 x 6-10 $\mu \mathrm{m}$. Phialides mixtus appressoriis, oppositae, alternatae vel unilateralis, ampulliformes, 12-19 x 6-10 $\mu \mathrm{m}$. Perithecia dispersa vel aggregata, ad $160 \mu \mathrm{m}$ diam.; cellulae peritheciales mammiformes, ad $16 \mu \mathrm{m}$ longae; ascosporae obovoideae, 4septatae, constrictae ad septatae, 33-38 x 17-19 $\mu \mathrm{m}$.

Colonies epiphyllous, dense, up to $2 \mathrm{~mm}$ in diameter, confluent. Hyphae straight, substraight to flexuous, branching mostly opposite to alternate at acute to wide angles, loosely to closely reticulate, cells 9-24 x 6-8 $\mu \mathrm{m}$. Appressoria alternate to unilateral, straight to slightly curved, antrorse to subantrorse, rarely retrorse, 12-2 $1 \mu \mathrm{m}$ long; stalk cells cylindrical to cuneate, 3-8 $\mu \mathrm{m}$ long; head cells straight to slightly curved, globose,

Date of publication (online): 26 September 2009

Date of publication (print): 26 September 2009

ISSN $0974-7907$ (online) | 0974-7893 (print)

Editor: R.K. Verma

\section{Manuscript details:}

Ms \# 02065

Received 13 September 2008

Final received 18 June 2009

Finally accepted 22 June 2009

Citation: Hosagoudar, V.B., G.R. Archana \& T. Sabu (2009). Asteridiella ficicola sp. nov. (Meliolaceae) from Kerala, India. Journal of Threatened Taxa 1(9): 474

Copyright: (C) V.B. Hosagoudar, G.R. Archana \& T. Sabu 2009. Creative Commons Attribution 3.0 Unported License. JoTT allows unrestricted use of this article in any medium for non-profit purposes, reproduction and distribution by providing adequate credit to the authors and the source of publication.

Acknowledgement: We thank Director, TBGRI, Palode for the facilities. We are grateful to Ministry of Environment and Forest, New Delhi for the financial support and to Forest Department, Govt. of Kerala for permission. ovate, oblong, entire to rarely angular, 813 x 6-10 $\mu \mathrm{m}$. Phialides mixed with appressoria, opposite, alternate to unilateral, ampulliform, 12-19 x 6-10 $\mu \mathrm{m}$. Perithecia scattered to grouped, up to $160 \mu \mathrm{m}$ in diam., perithecial wall cells mammiform, up to $16 \mu \mathrm{m}$ long; ascospores obovoidal, 4-septate, constricted at the septa, 33-38 x 17-19 $\mu \mathrm{m}$.

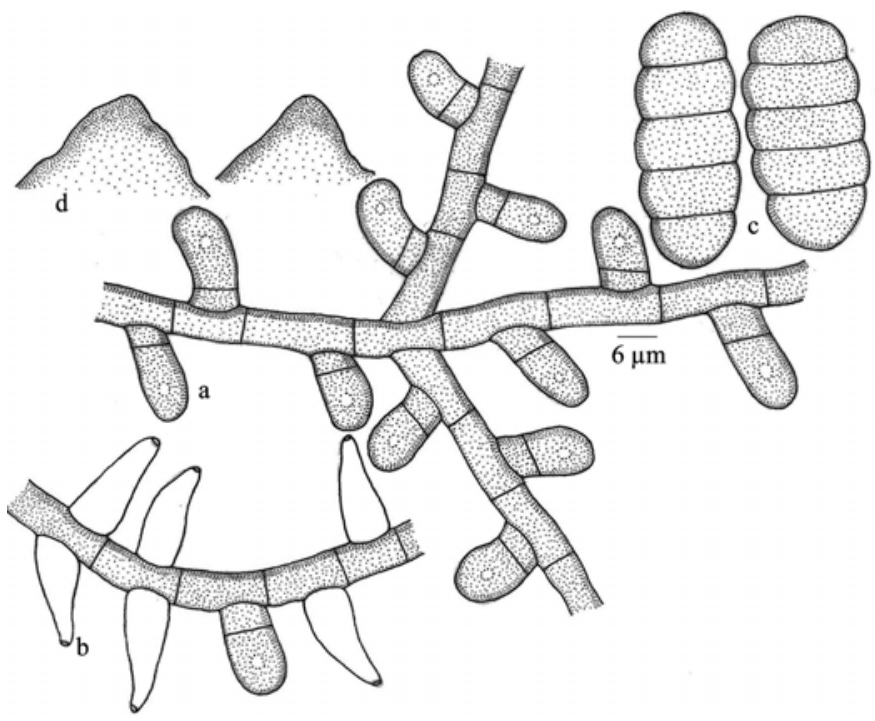

Figure 1. Asperidiella ficicola sp. nov.

a - Appressorium; b - Phialide; c - Ascospores; d - Perithecial wall cells

\section{Material examined}

Types: 4.i.2006, on leaves of Ficus microcarpa L. (Moraceae), Arboretum, TBGRI Campus, Palode, Thiruvananthapuram, Kerala, India, coll. T. Sabu, HCIO 46806 (type), TBGT 2147 (isotype) (Myco Bank \# MB5 13420).

\section{Remarks}

Based on the Beeli formula 3101.3220 , this species is similar to Asteridiella olmediae Hansf. reported on Olmedia aspera from Panama. However, Asteridiella ficicola differs from it in having only epiphyllous and confluent colonies, shorter appressoria with mostly ovate to oblong head cells (Hansford 1961; Hosagoudar 1996).

In some perithecia, marginal cells were radiating and reminding of the genus Amazonia. However, most of the perithecia were globose so as to accommodate it in the genus Asteridiella.

\section{References}

Hansford, C.G. (1961). The Meliolineae. A Monograph. Sydowia Beih. 2: $1-806$.

Hosagoudar, V.B. (1996). Meliolales of India. BSI, Calcutta, 363pp. 